INTERNATIONAL JOURNAL
OFF
PHARMACEUTICAL SCIENCES
RESEARCH

Received on 23 April, 2010; received in revised form 05 June, 2010; accepted 01 August, 2010

\title{
FORMULATION AND DEVELOPMENT OF FAST DISINTEGRATING FELODIPINE TABLETS: FUNCTIONALITY OF SUPERDISINTEGRANTS
}

Hariprasanna RC, Upendra Kulkarni*, Basawaraj S Patil Vipul Karkar and Parikh Bhavik

R.M.E.S's College of Pharmacy, Gulbarga, Karnataka, India

Keywords:

Fast Disintegrating Tablet,

Felodipine,

Croscarmellose sodium,

Crosspovidone,

Sodium Starch Glycolate

Correspondence to Author:

Upendra Kulkarni

Department of Pharmaceutics, R. M. E. S's College of Pharmacy, Gulbarga, Karnataka, India

E-mail: upendra613@gmail.com

\section{ABSTRACT}

Felodipine, a calcium channel blocker, is used for hypertension and angina pectoris. Felodipine fastdisintegrating tablets (FDT) have been prepared by direct compression method. Effect of superdisintegrants (like crosspovidone, croscarmellose sodium and sodium starch glycolate) on wetting time, disintegrating time, drug content, in vitro release and stability parameter has been studied. Disintegrating time and dissolution parameter ( $t_{50} \%$ and $t_{90} \%$ ) decreased with increases in the level of croscarmellose sodium and crosspovidone whereas disintegration time and dissolution parameter increased with increase in the level of more than $5 \%$ sodium starch glycolate. The formulation did not show any change in disintegration time, wetting time and drug content after stability period. It was concluded that fast disintegrating Felodipine tablets can be prepared by direct compression using superdisintegrants.

Available online on www.ijpsr.com 
INTRODUCTION: Felodipine is a dihydropyridine derivative, that is chemically described as ethyl methyl- 4 (2, 3, dichlorphenyl) - 1- 4- dihydro- 2, 6- dimethyl pyridine- 3, 5- dicarboxylate.

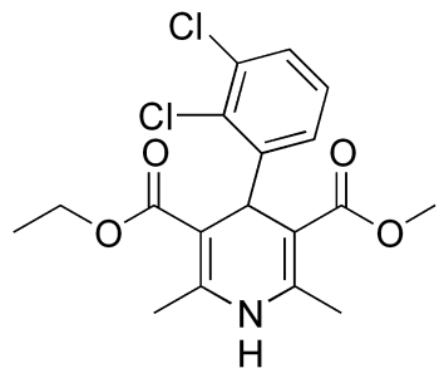

FELODIPINE

Felodipine is almost completely absorbed from the gastrointestinal tract after oral doses but undergoes extensive first pass metabolism, with a bioavailability of about $15 \%$. It is extensively metabolized in the gut and the liver and is excreted almost entirely as metabolites, about $70 \%$ of a dose being excreted in urine and the remainder in feces. The terminal elimination half life is reported to be 11 to 16 hours after oral administration. Felodipine is about $99 \%$ bound to plasma proteins ${ }^{1-4}$.

The fast disintegrating drug delivery systems is rapidly gaining acceptance as an important novel drug delivery system. This delivery system offers better patient compliance than conventional tablet dosage form ${ }^{5}$. Bioavailability of drug from this delivery system is significantly greater than conventional tablets ${ }^{6}$. Fast disintegrating tablets are not only indicated for people having difficulty in swallowing but also ideal for unfavorable conditions of administration where water is not available. Syrups are best for pediatrics but they are bulky and drugs are not as stable in liquid form as in solid form ${ }^{7}$. After keeping the FDT on tongue, immediately it disintegrates, releasing the drug which dissolves or disperses in the saliva. Some drugs are absorbed from the mouth, pharynx and esophagus, as the saliva passes down into the stomach, in such cases bioavailability of drug is significantly greater than conventional dosage form ${ }^{8}$. Main advantages of direct compression are low manufacturing cost and high mechanical integrity of the tablets ${ }^{9-10}$. Therefore, direct compression appears to be a better option for manufacturing of tablets. The fast disintegrating tablets prepared by direct compression method in general, are based on the action established by superdisintegrants like croscarmellose sodium (CCS), crosspovidone (CP) and sodium starch glycolate (SSG). The effect of functionality difference of the superdisintegrants on tablet disintegration has been studied ${ }^{11}$. The objective of the present investigation was to develop fast disintegrating Felodipine tablets by direct compression method and to study the effect on functionality differences of superdisintegrants on the tablet properties.

MATERIALS AND METHODS: Felodipine was gifted from Cipla limited Bangalore, Croscarmellose sodium, crosspovidone, sodium starch glycolate. Gift sample from Maple biotech Pvt. Ltd, Pune, Microcrystalline cellulose, Dmannitol, Talc and Magnesium stearate, were purchased from S.D. Fine chemicals Pvt. limited, Mumbai and all other materials were of analytical grade.

\section{METHODS:}

Preparation of Tablets by Direct Compression Method: Tablets containing $5 \mathrm{mg}$ of Felodipine were prepared by direct compression method and the formula used is shown in table-1. The drug, diluent and superdisintegrants were mixed together in a plastic container. Talc and Magnesium stearate were passed through sieve no. 60 , mixed and blended with initial mixture in the plastic container followed by compression of the blend. 
TABLE 1: FORMULA USED IN THE PREPARATION OF TABLETS

\begin{tabular}{cccccccccc}
\hline $\begin{array}{c}\text { Ingredients } \\
\text { (mg/tablet) }\end{array}$ & \multicolumn{7}{c}{ FORMULATIONS } \\
\cline { 2 - 10 } & F1 & F2 & F3 & F4 & F5 & F6 & F7 & F8 & F9 \\
\hline Felodipine & 5 & 5 & 5 & 5 & 5 & 5 & 5 & 5 & 5 \\
Lactose & 114.5 & 113 & 110 & 114.5 & 113 & 110 & 113 & 110 & 107 \\
CC5* & 1.5 & 3 & 6 & - & - & - & - & - & - \\
CP** & - & - & - & 1.5 & 3 & 6 & - & - & - \\
SSG*** & - & - & - & - & - & - & 3 & 6 & 9 \\
MCC**** & 20 & 20 & 20 & 20 & 20 & 20 & 20 & 20 & 20 \\
DC- Mannitol & 6 & 6 & 6 & 6 & 6 & 6 & 6 & 6 & 6 \\
Talc & 1.5 & 1.5 & 1.5 & 1.5 & 1.5 & 1.5 & 1.5 & 1.5 & 1.5 \\
Mg. Stearate & 1.5 & 1.5 & 1.5 & 1.5 & 1.5 & 1.5 & 1.5 & 1.5 & 1.5 \\
\hline Total Weight & $\mathbf{1 5 0}$ & $\mathbf{1 5 0}$ & $\mathbf{1 5 0}$ & $\mathbf{1 5 0}$ & $\mathbf{1 5 0}$ & $\mathbf{1 5 0}$ & $\mathbf{1 5 0}$ & $\mathbf{1 5 0}$ & $\mathbf{1 5 0}$ \\
\hline
\end{tabular}

*: Croscarmellose Sodium; **: Crosspovidone; ${ }^{* * *}$ : Sodium starch Glycolate; ${ }^{* * * *}$ : Micro crystalline cellulose

Evaluation of Felodipine disintegrating tablets: All prepared tablets were evaluated for hardness, thickness, friability, disintegration time, wetting time, drug content and stability studies. Pfizer hardness tester was used for the determination of the hardness of the tablets. The tablet was placed in contact between the plungers and the handle was pressed, the force of the fracture was recorded.The thickness of tablets were recorded during the process of compression using Calipers (Mitotoyo; Japan).

The friability of the tablets was determined using a Roche Friabilator (Electrolab, EF-2 Friabilator) by taking two tablets from each batch and accurately weighed and placed in the Friabilator then operated for 100 revolutions .Then the tablets were dedusted and reweighed .Percentage friability was calculated using the formula, $F=(1-w o / w) * 100$. In the disintegration time study, the tablets were taken and introduced in each tube of disintegration apparatus, and the tablet rack of the disintegration apparatus was positioned into a 1 liter beaker containing $900 \mathrm{ml}$ of phosphate buffer pH 6.5 containing $0.1 \%$ SLS and time of disintegration was recorded at $37 \pm 2{ }^{\circ} \mathrm{C}$. In the wetting time study, a piece of tissue paper folded twice was placed in a petridish (with internal diameter $6.5 \mathrm{~cm}$ ) containing $5 \mathrm{ml}$ of distilled water. A tablet was placed on the paper and the time for complete wetting of the tablet was measured in seconds. For drug content analysis a total 10 tablets were weighed and powdered. The powder equivalent to $5 \mathrm{mg}$ of Felodipine was taken and dissolved in phosphate buffer $\mathrm{pH} 6.5$ containing $0.1 \%$ SLS .After that an aliquot of the filtrate was diluted and analyzed spectrophotometrically (UV-1700 Shimadzu Corporation, Japan) at $362 \mathrm{~nm}$. The stability study of the tablets was carried out according to $\mathrm{ICH}$ guidelines. The formulations were stored at 40 $\pm 2^{\circ} \mathrm{C} / 75 \pm 5 \% \mathrm{RH}$ for 4 weeks in a stability chamber (Labcare, Mumbai, India). 
In- vitro Release Studies: The invitro dissolution study was carried out in the USP dissolution test apparatus (Electrolab TDT - 08 L Dissolution tester USP) type 2 (paddle). $900 \mathrm{ml}$ of the dissolution medium (Phosphate buffer $\mathrm{pH} 6.5$ containing $0.1 \%$ SLS) was taken in vessel and the temperature was maintained at $37 \pm 0.5^{\circ} \mathrm{C}$. The speed of the paddle was set at $50 \mathrm{rpm} .5 \mathrm{ml}$ of the dissolution medium was withdrawn and the same amount of fresh medium was replenished to the dissolution medium. The sample withdrawn was filtered and diluted with Phosphate buffer $\mathrm{pH} 6.5$ containing $0.1 \%$ SLS prior to analysis in the UV Spectrophotometer (UV-1700 Shimadzu Corporation, Japan) at $362 \mathrm{~nm}$.

RESULTS AND DISCUSSIONS: The values of precompressional parameters evaluated were within prescribed limits and indicated a good free flowing property. Results are shown in Table 2. The post compression parameters such as hardness, friability, thickness, disintegration time, wetting time, $\mathrm{t}_{50} \%, \mathrm{t}_{90} \%$ and drug content are shown in Table 3 and Table 4.

TABLE 2: PRECOMPRESSIONAL PARAMETERS:

\begin{tabular}{cccc}
\hline Formulation & $\begin{array}{c}\text { Angle of Repose }(\boldsymbol{\theta}) \\
( \pm S D), n=3\end{array}$ & $\begin{array}{c}\text { Compressibility (\%) } \\
( \pm S D), n=3\end{array}$ & $\begin{array}{c}\text { Hausner's Ratio } \\
\text { ( } \pm S D), n=3\end{array}$ \\
\hline F1 & $24.12 \pm 1.52$ & $23.60 \pm 1.57$ & $1.32 \pm 0.04$ \\
F2 & $23.56 \pm 1.22$ & $25.22 \pm 2.50$ & $1.33 \pm 0.06$ \\
F3 & $22.70 \pm 0.28$ & $23.61 \pm 0.75$ & $1.35 \pm 0.06$ \\
F4 & $23.33 \pm 0.25$ & $20.00 \pm 1.20$ & $1.32 \pm 0.05$ \\
F5 & $22.81 \pm 1.44$ & $27.42 \pm 0.65$ & $1.37 \pm 0.04$ \\
F6 & $20.76 \pm 0.35$ & $21.57 \pm 1.67$ & $1.28 \pm 0.07$ \\
F7 & $22.58 \pm 0.90$ & $22.41 \pm 0.75$ & $1.34 \pm 0.05$ \\
F8 & $22.70 \pm 2.20$ & $24.44 \pm 0.32$ & $1.24 \pm 0.05$ \\
F9 & $22.99 \pm 0.72$ & $25.50 \pm 1.50$ & \\
\hline
\end{tabular}

Note: Values in parenthesis are standard deviation ( \pm SD)

TABLE 3: POST COMPRESSIONAL PARAMETERS OF FELODIPINE TABLETS

\begin{tabular}{|c|c|c|c|c|c|c|}
\hline Formulation & $\begin{array}{l}\text { Hardness Test } \\
\begin{array}{l}(\mathrm{kg} / \mathrm{cm} 2) \\
\pm S D, \mathrm{n}=6\end{array}\end{array}$ & $\begin{array}{c}\text { Friability (\%) } \\
\pm S D, n=10\end{array}$ & $\begin{array}{c}\text { Thickness (mm) } \\
\pm S D, n=4\end{array}$ & $\begin{array}{l}\text { Disintegration Time } \\
\text { (sec) } \\
\pm S D, n=6\end{array}$ & $\begin{array}{l}\text { Wetting Time (sec) } \\
\pm S D, n=6\end{array}$ & $\begin{array}{c}\text { Drug Content } \\
\text { (\%) } \\
\pm S D, n=6\end{array}$ \\
\hline F1 & $4.0 \pm 0.01$ & $0.7 \pm 0.07$ & $3.65 \pm 0.05$ & 52.5 & 65.5 & $99.00 \pm 1.55$ \\
\hline F2 & $4.1 \pm 0.31$ & $0.5 \pm 0.06$ & $3.48 \pm 0.06$ & 48.3 & 58.3 & $101.00 \pm 2.20$ \\
\hline F5 & $4.4 \pm 0.18$ & $0.7 \pm 0.08$ & $3.80 \pm 0.06$ & 38.0 & 47.5 & $101.00 \pm 2.50$ \\
\hline F6 & $4.2 \pm 0.50$ & $0.4 \pm 0.06$ & $3.84 \pm 0.06$ & 18.3 & 31.3 & $102.00 \pm 0.55$ \\
\hline F7 & $4.1 \pm 0.33$ & $0.3 \pm 0.04$ & $3.66 \pm 0.07$ & 70.0 & 88.4 & $99.23 \pm 1.13$ \\
\hline
\end{tabular}

Note: Values in parenthesis are standard deviation ( \pm SD) 
TABLE 4: DISSOLUTION STUDY OF FELODIPINE FORMULATION

\begin{tabular}{|c|c|c|c|c|c|c|c|c|c|}
\hline \multirow{2}{*}{$\begin{array}{l}\text { Time } \\
(\min )\end{array}$} & \multicolumn{9}{|c|}{ FORMULATIONS/PERCENTAGE DRUG RELEASE } \\
\hline & F1 & F2 & F3 & F4 & F5 & F6 & F7 & F8 & F9 \\
\hline 0 & 0 & 0 & 0 & 0 & 0 & 0 & 0 & 0 & 0 \\
\hline 5 & 33.18 & 34.28 & 36.20 & 34.30 & 37.40 & 38.00 & 33.00 & 35.00 & 28.00 \\
\hline 10 & 40.70 & 42.30 & 45.00 & 44.50 & 45.50 & 47.50 & 40.10 & 43.00 & 35.00 \\
\hline 15 & 50.30 & 52.32 & 53.82 & 53.50 & 54.50 & 56.50 & 50.50 & 52.50 & 40.30 \\
\hline 20 & 60.30 & 61.50 & 63.20 & 62.10 & 63.50 & 55.30 & 59.10 & 60.20 & 50.50 \\
\hline 30 & 77.00 & 79.30 & 80.30 & 79.30 & 80.10 & 85.00 & 76.30 & 77.50 & 60.50 \\
\hline 45 & 89.00 & 91.50 & 92.50 & 91.34 & 92.50 & 97.50 & 88.50 & 90.10 & 72.30 \\
\hline 60 & 91.34 & 98.00 & 99.10 & 97.10 & 99.00 & 100.00 & 90.10 & 99.00 & 84.00 \\
\hline
\end{tabular}

In all the formulations, the hardness test indicates good mechanical strength. Friability of all formulations was less than $1 \%$, which indicated that the tablets had a good mechanical resistance. Drug content was found to be high $(\geq 102.00 \%)$ and uniform in all the formulations. The important parameter that requires to be optimized in the development of the fast disintegrating tablets is the disintegration time of the tablets. In the present investigation, all the tablets disintegrated in $\leq 100$ seconds fulfilling the official requirements ( $<3 \mathrm{~min}$.) for disintegrating tablets ${ }^{12}$, formulation F9, which disintegrated $100 \mathrm{sec}$.

The absorption of water is an important step for the subsequent disintegration process of tablets ${ }^{13}$. Bi et. al. ${ }^{14}$ have reported that when higher concentration of superdisintegrants were added to the tablet formulation, they absorbed considerable amount of water and resulted in increase in viscosity of fluid within the tablet mass. This delayed further water penetration into the tablets. Therefore, it was decided to use superdisintegrants concentrations only up to $5 \%$ $w / w$. The disintegration time of the tablets decreased (from 52.5-20 sec) with increase in the level of croscarmellose sodium (F1- F3). The disintegration time of tablets decreased (42.5$18.3 \mathrm{sec}$ ) with increase in the level crosspovidone (F4- F6). The disintegration time of tablets decreased (from 70- $65 \mathrm{sec}$ ) with increase in the level of sodium starch glycolate (F7- F8). However, disintegration time is increased with increase in the level of sodium starch glycolate in the formulation F9, (100 sec). It indicates that increase in the level of SSG had a negative effect on the disintegration of the tablets ${ }^{15}$.

At higher levels, formulation of a viscous gel layer by SSG ${ }^{16}$ might have formed a thick barrier to the further penetration of the disintegration medium and hindered the disintegration or leakage of tablet contents ${ }^{15}$. The disintegration time of crosspovidone containing tablets are comparatively lower than those containing croscarmellose sodium and sodium starch glycolate. The faster disintegration of crosspovidone tablets may be attributed to its rapid capillary activity and pronounced hydration with little tendency to gel formation ${ }^{17}$. 
The influence of superdisintegrants on the dissolution of Felodipine from the tablets is shown in Fig. 1. The $t_{50} \%$ and $t_{90} \%$ values decreased $(p<0.05)$ with increase in the level of superdisintegrants in formulations from F1-F8. An increase value of $t_{50} \%$ and $t_{90} \%$ can be seen in formulation F9. It may be due to higher concentration of sodium starch glycolate. At higher concentration sodium starch glycolate provides viscous gel layer, which leads to formulation of a thick barrier to the further penetration of the dissolution medium and hindered the dissolution of tablet content ${ }^{15}$.

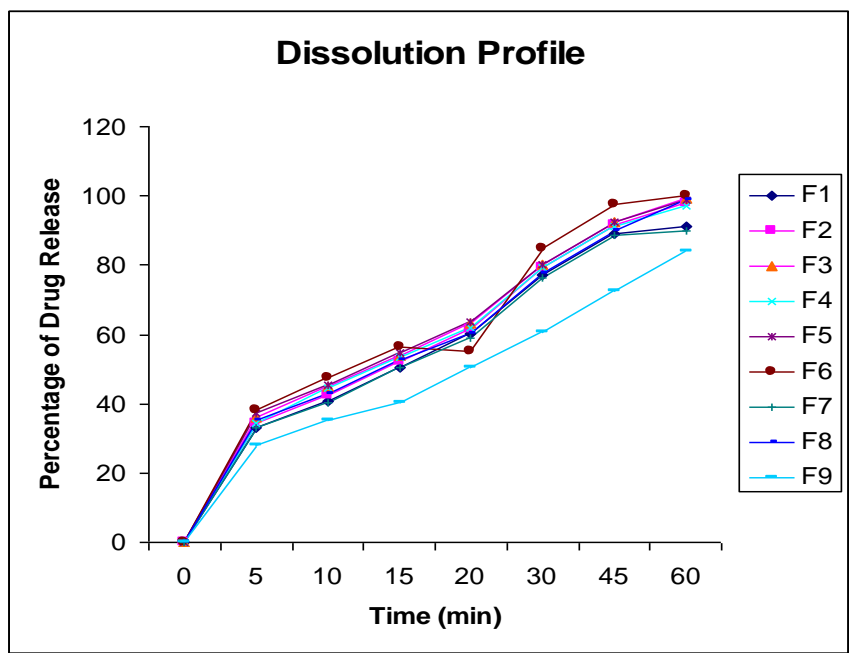

FIG. 1: DISSOLUTION PROFILE OF TABLETS CONTAINING FELODIPINE

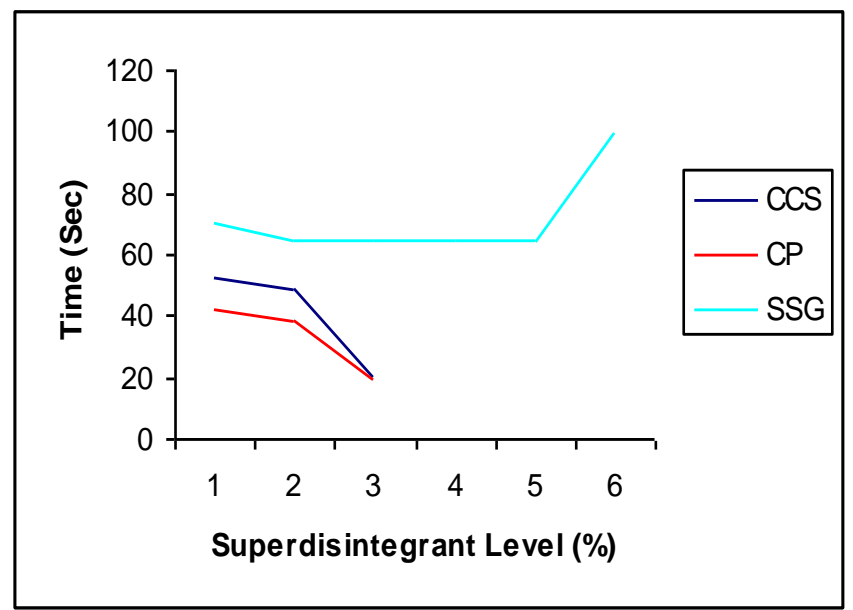

FIG. 2: EFFECT OF CONCENTRATION OF CCS, CP AND SSG ON DISINTEGRATION TIME OF TABLETS

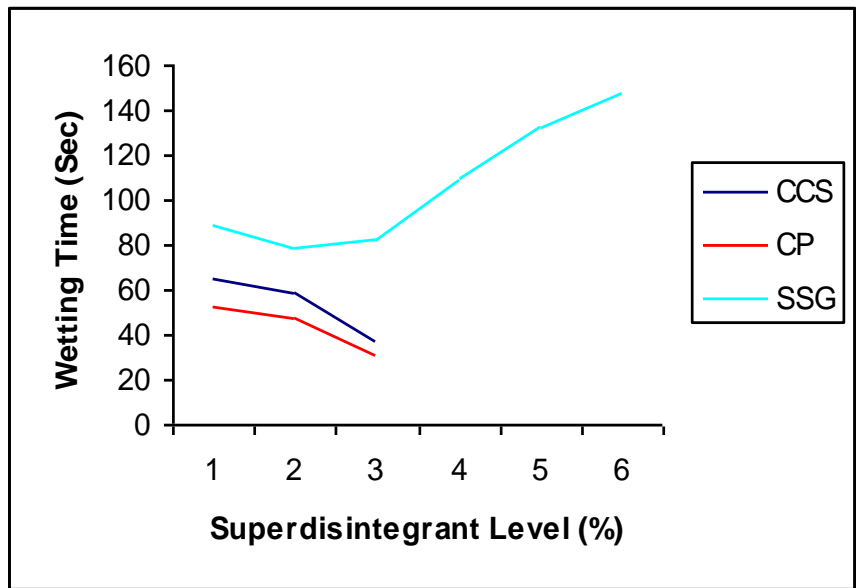

FIG. 3: EFFECT OF CONCENTRATION OF CCS, CP AND SSG ON WETTING TIME OF TABLETS

It was concluded that, although functionality difference existed between the superdisintegrants, the fast disintegrating Felodipine tablets can be prepared by using any of the superdisintegrants used. The stability study for all the formulations were carried out according to the $\mathrm{ICH}$ guidelines at $40 \pm 2{ }^{\circ} \mathrm{C} / 75 \pm 5 \%$ $\mathrm{RH}$ for 4 weeks, by storing the tablets in a stability chamber (Labcare, Mumbai, India) . No change was observed in the disintegration time of all the formulations. No significant change in the thickness was observed in all the formulations and drug content of all formulations was within the acceptable limits. Results are shown in Table 5.

\section{TABLE 5: TABLET PARAMETERS AFTER STABILITY STUDY}

\begin{tabular}{cccc}
\hline Formulations & $\begin{array}{c}\text { Disintegration } \\
\text { time } \\
\text { (Sec) } \pm \text { SD, } \mathbf{n}=\mathbf{3}\end{array}$ & $\begin{array}{c}\text { Wetting } \\
\text { time (Sec) } \\
\pm S D, n=3\end{array}$ & $\begin{array}{c}\text { Drug content } \\
(\%) \pm S D, n=3\end{array}$ \\
\hline F1 & 52.0 & 65.0 & $99.00 \pm 1.00$ \\
F2 & 47.9 & 58.2 & $100.00 \pm 1.20$ \\
F3 & 20.0 & 37.3 & $99.00 \pm 2.50$ \\
F4 & 41.8 & 52.0 & $99.30 \pm 1.50$ \\
F5 & 37.8 & 47.2 & $100.50 \pm 2.30$ \\
F6 & 18.0 & 31.2 & $101.50 \pm 1.40$ \\
F7 & 69.5 & 88.2 & $99.00 \pm 2.50$ \\
F8 & 64.7 & 78.5 & $99.00 \pm 1.10$ \\
F9 & 99.3 & 146.2 & $99.50 \pm 2.20$ \\
\hline
\end{tabular}




\section{REFERENCES:}

1. Martindale. The complete drug reference. $34^{\text {th }}$ ed. London: Pharmaceutical Press; 2005.

2. British National Formulary. 52ed. London: British Medical Association and Royal Pharmaceutical Society of Great Britain; 2006.

3. Clark's Analysis of Drug and Poisons, London; Pharmaceutical Press. Electronic version, 2006.

4. Evangelos Karavas, Emmanouel Georgarakis, Dimitrios Bikiaris: Application of PVP/HPMC miscible blends with enhanced mucoadhesive properties for adjusting drug release in predictable pulsatile chronotherapeutics. J Pharm sci, 2006; 64:115-126.

5. Indurwade NH, Rajyaguru TH, Nakhat PD: Novel approachFast dissolving tablets. Indian Drugs. 2002; 39: 405-409.

6. Kuchekar BS, Badhan AC, Mahajan HS: Mouth dissolving tablet: A novel Drug delivery system. Pharma Times. 2003; 35: 7-14.

7. Manthan MJ, Udhav SB: Review Manufacturing Technology for Mouth Dissolving Tablets. March 2007; 1-7.

8. Adleeb Ahmad: Functional Foods and Nutraceuticals, New Technology Delivers Faster Melting Tablets. March 2004; 1-3.

9. Bi $\mathrm{Y}$, Sunada $\mathrm{H}$, Yonezawa $\mathrm{Y}$, Danjo $\mathrm{K}$, Otsuka A, lida K: Preparation and evalution of a compressed tablet rapidly disintegrating in the oral cavity. Chem. Pharm. Bull 1996; 44: 2121-7.

10. Patrick K, Sang KW. Method of Making freeze-dried dosage form. US Patent 5631 023; 1997.
11. Zhao N, Augsburger LL. Functionality comparison of 3 Classes of superdisintegrants in promoting aspirin tablet disintegration and dissolution. AAPS PharmSciTech 2005;6: Article 79.

12. European department for the quality of medicines. In: European Pharmacopoeia. $3^{\text {rd }}$ ed. Strasbourg: Supplement; 2001; 1666-9.

13. Deshmukh Sambhaji S, Potnis Vaishali V, Mahaparle Paresh R, Kasture Pramod V and Ghare Vikram S: Development of Evalution of Ziprasidone Hydrochloride Fast Disintegrating/ Dissolving Tablets using Complexation Techniques. Indian J. Pharm. Educ. Res Jul-Sept.2009;3: 43.

14. Bi YX, Sunada $H$, Yonezawa $Y$ : Evalution of rapidly disintegrating tablets prepared by direct compression method. Drug Dev Ind Pharm. 1999; 25: 571-581.

15. C. Mallikarjun Setty, DVK. Prasad, VRM Gupta and B SA: Development of Fast Dispersible Aceclofenac Tablets: Effect of Functionality of Superdisintegrants. Indian J. Pharm. Sci., 2008; 70 (2): 180-185.

16. Bolhuis GK, Zuurman K, te Wierik GH. Improvement of dissolution of poorly drug by solid deposition on a superdisintegrrant; II, The choice of superdisintegrants and effect of granulation. Eur J Pharm Sci 1997; 5: 63-9.

17. Rowe RC, Sheskey PJ, Weeler PJ, editors. Handbook of pharmaceutical excipients $4^{\text {th }} \mathrm{ed}$. London and Washington DC: The Pharmaceutical Press; 2003. 